\title{
Endodontic irrigants: Different methods to improve efficacy and related problems
}

\author{
Mario Dioguardi ${ }^{1}$, Giovanni Di Gioia ${ }^{1}$, Gaetano Illuzzi ${ }^{1}$, Enrica Laneve ${ }^{1}$, Armando Cocco $^{1}$, \\ Giuseppe Troiano ${ }^{1}$
}

Correspondence: Dr. Giuseppe Troiano

Email: giuseppe.troiano@unifg.it
'Department of Clinical and Experimental Medicine, Foggia University, Foggia, Italy

\section{ABSTRACT}

Shaping and cleaning a root canal system along with the preservation of the surrounding periodontal tissues are the principal goals of an endodontic treatment. While most of the attention is paid to the mechanical aspects of a root canal treatment, an essential feature of it is the irrigation. All over the years, many materials have been used to clean the root canal of a tooth, and certainly, the sodium hypochlorite $(\mathrm{NaOCl})$ and ethylenediaminetetraacetic acid solutions are the most used and most reliable ones. Putting them inside of a canal is mostly done using a normal syringe, but many techniques have been involved in this process, including the use of sonic/ultrasonic instruments, the use of shaping files, and even laser, to increase the efficacy of irrigant solutions, especially of $\mathrm{NaOCl}$ one. Each one of this technique faces some disadvantages, just as the vapor lock effect and the apical extrusion, and has a different action on features such as the reaction rate and the shear stress of an endodontic irrigant solution. In this narrative review, we describe the different features of many irrigant solutions and the different ways of upgrading their efficacy in the cleaning of a root canal system, with the use of tables to summarize the entire description, and drawing the readers' attention to a photographic illustration for a better understanding of the topic.

Key words: Canal disinfection, citric acid, endodontics, ethylenediaminetetraacetic acid, irrigants, root canal therapy, sodium hypochlorite

\section{INTRODUCTION}

The removal of both necrotic and vital pulp substrates and microorganisms and their toxins from the root canal system is the basis for a successful endodontic treatment. ${ }^{[1]}$ It has been shown that endodontic lesions do not develop in the absence of bacteria. ${ }^{[2]}$ Primary infections of the endodontic space are mainly caused by obligate anaerobic species, ${ }^{[3]}$ while the most responsible one for endodontic failure is Enterococcus faecalis. ${ }^{[4]}$ This bacterium is able to withstand many intracanal medications ${ }^{[5-7]}$ and also represents an important microorganism in the biofilm development,

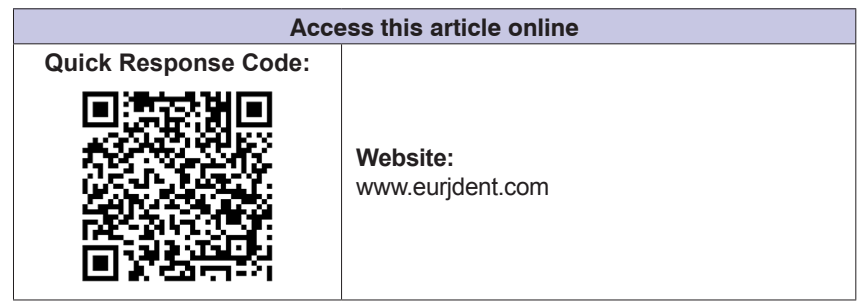

even though some articles suggest that calcium hydroxide is able to kill it. ${ }^{[8-11]}$

During the cleaning and shaping phases of an endodontic treatment, it is possible to distinguish chemical and mechanical cleansing. ${ }^{[12,13]}$

Mechanical cleansing, in addition to the removal of necrotic or vital pulp tissue, leads to the formation of a thin layer of debris, known as "smear layer." ${ }^{[14,15]}$ This layer is made up of potentially infective organic and

This is an open access journal, and articles are distributed under the terms of the Creative Commons Attribution-NonCommercial-ShareAlike 4.0 License, which allows others to remix, tweak, and build upon the work non-commercially, as long as appropriate credit is given and the new creations are licensed under the identical terms.

For reprints contact: reprints@medknow.com

How to cite this article: Dioguardi M, Di Gioia G, Illuzzi G, Laneve E, Cocco A, Troiano G. Endodontic irrigants: Different methods to improve efficacy and related problems. Eur J Dent 2018;12:459-66.

DOI: 10.4103/ejd.ejd_56_18 
inorganic substances that must be removed from the canal walls, dentin tubules, and root canal branches with the aid of root canal irrigants.

The presence of isthmi and anastomosis can make the chemical cleansing of the root canal system very difficult since they can be filled with the smear layer. ${ }^{[16,17]}$

The ideal features of root canal irrigants include the cleansing lubrication of endodontic instruments and root canal system, the dissolution of inorganic and organic substances, the antimicrobial action, the absence of cytotoxicity, and the inefficacy in the alteration of dental microstructure. ${ }^{[18,19]}$

\section{MATERIALS AND METHODS}

The data collection for this narrative review has been performed using the following online databases: PubMed, Ebsco Library, and Web of Science. Only the articles published in the last 40 years have been taken into consideration. The search has been performed in a standardized manner by two reviewers of the dental clinic of the University of Foggia. All the outcomes have been obtained by entering the following keywords or combination of words: endodontic irrigants and vapour lock or effect, apical extrusion and root canal irrigants, or sodium hypochlorite activation and endodontic irrigants activation. The number of results obtained by entering these keywords is illustrated in Table 1. The article types selected include reviews, clinical trials, and in vitro studies; moreover, all their abstracts have been analyzed to exclude those which are irrelevant or not written in English. For the discussion, many articles written on peer-reviewed journals in the endodontic field, such as the International Endodontic Journal and Journal of Endodontics, have been principally taken into consideration.

All the articles entered in the reference list have been fully studied and discussed. This database search has been done from December 2017 to February 2018.

\section{RESULTS}

Using a normal syringe for the irrigation of the root canal system is the most common and the easiest way performed in the clinical practice. By the way, it faces a series of problems just as the vapor lock effect [Figure 1] and a lower degree of disinfection, if compared to its mechanical activation using shaping files or even more by increasing its temperature. These two last methods result having a lower efficacy in the vapor lock removal, especially if compared to the activation of irrigants using sonic/ultrasonic instruments or even to the adoption of a negativepressure gradient, as a way of both delivering and removing the irrigant solutions inside the root canal system. Among these methods, there are many pros and cons about different features: reaction rate, shears stress, apical extrusion of the solution, alteration of the root anatomy, and cost. The use of photoactivation methods, such as laser-activated irrigation (LAI) and photon-induced photoacoustic streaming (PIPS), can increase the reaction rate of the irrigants, but certainly, they have an even increased cost. A more detailed description about the methods listed above will follow in the discussion section.

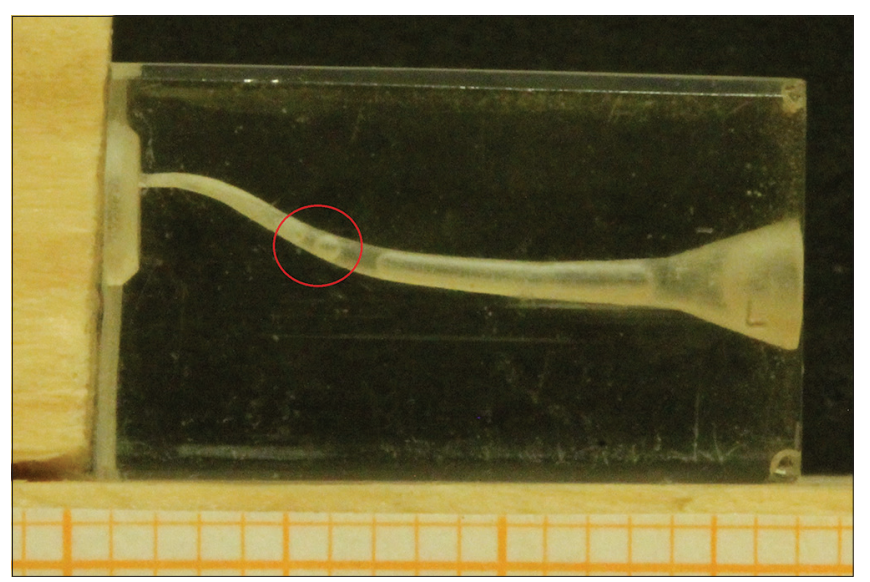

Figure 1: Presence of vapor lock in a simulated root canal

\begin{tabular}{|c|c|c|c|c|c|c|}
\hline & \multicolumn{2}{|c|}{ PubMed (search bar) } & \multicolumn{2}{|c|}{ Web of science (search topics) } & \multicolumn{2}{|c|}{ Ebsco library (all databases, search all terms) } \\
\hline & All & Excluded & All & Excluded & All & Excluded \\
\hline $\begin{array}{l}\text { Endodontic irrigants } \\
\text { activation }\end{array}$ & 45 results & 10 & 51 results & 4 & 98 results & 7 \\
\hline $\begin{array}{l}\text { Apical extrusion and } \\
\text { root canal irrigants }\end{array}$ & 81 results & 26 & 19 results & 3 & 54 results & 7 \\
\hline $\begin{array}{l}\text { Endodontic irrigants } \\
\text { and vapor lock }\end{array}$ & 1 result & 0 & 4 results & 0 & 7 results & 0 \\
\hline $\begin{array}{l}\text { Sodium hypochlorite } \\
\text { activation }\end{array}$ & 206 results & 99 & 244 results & 136 & 328 results & 326 \\
\hline
\end{tabular}




\section{DISCUSSION}

\section{Irrigants commonly used in endodontics}

The root canal irrigants used in the chemical cleansing phase are divided into those with antibacterial action and those with decalcifying action. ${ }^{[20]}$ The most common irrigants are sodium hypochlorite $(\mathrm{NaOCl})$, citric acid, ethylenediaminetetraacetic acid (EDTA), and chlorhexidine. ${ }^{\left[{ }^{[1]} \mathrm{NaOCl}\right.}$ is the most widely used irrigant. ${ }^{[22]}$ When poured in water, it dissociates in $\mathrm{Na}^{+}$and $\mathrm{OCl}^{-}$ions. At neutral or acid $\mathrm{pH}$, the predominant form is $\mathrm{HOCl}$, which is responsible for the antimicrobial activity. $\mathrm{NaOCl}$ is used at concentrations ranging between $0.5 \%$ and $5.25 \% .{ }^{[23]}$

$\mathrm{NaOCl}$ is the only irrigant that can dissolve the necrotic and the less vital pulp residues [Figure 2], as well as the dentinal collagen, but not the smear layer.

The minimum antibacterial in vitro concentration of $\mathrm{NaOCl}$ is $0.5 \% .{ }^{[23]}$ However, in vivo, the presence of biofilm and organic material reduces $\mathrm{NaOCl}$ efficacy. ${ }^{[2]}$ Therefore, a continuous change of $\mathrm{NaOCl}$ and higher concentration seem to have more effect on the biofilm; however, it could expose the patient to more side effects. ${ }^{[24-27]}$

The critical points of $\mathrm{NaOCl}$ are its smell and toxicity and the impossibility of removing inorganic components deposited over anatomical regions, such as isthmi and anastomosis, because they are hard-to-reach spots to be mechanically cleaned by endodontic instruments.

Chlorhexidine digluconate is an endodontic irrigant with an efficient antibacterial activity in an endodontic

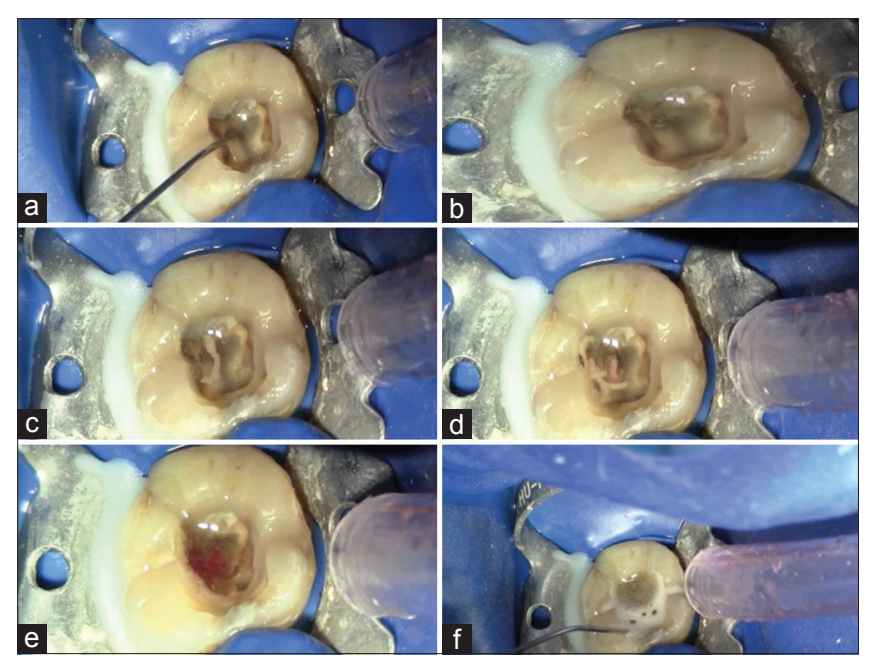

Figure 2: (a-f) Sequence of sodium hypochlorite action on a necrotic tissue environment, if used at a concentration of $2 \%$. Chlorhexidine digluconate cannot remove necrotic residues and cannot also be used as a substitute of $\mathrm{NaOCl}$. Its effectiveness is also reduced in the presence of organic residues inside the canal. ${ }^{[28,29]}$

The most common solution used to eliminate the inorganic residues, but not removed by $\mathrm{NaOCl}$, is a pH 7 solution of EDTA. EDTA has no antibacterial properties but can remove the smear layer deposited by the mechanical action of instruments, making the canal walls accessible again to disinfectants. ${ }^{[30,31]}$

The use of EDTA along with $\mathrm{NaOCl}$ immediately reduces the amount of available chlorine derived from $\mathrm{NaOCl} .{ }^{[32]}$ Moreover, the use of $\mathrm{NaOCl}$ after removing the smear layer induces dentinal erosion.

Among the various chelators used, citric acid causes a little enlargement of the tubules. At both $10 \%$ and $1 \%$ concentrations, it is more effective as a decalcifying agent compared to $17 \%$ concentrated EDTA. ${ }^{[33]}$ Some authors recommend using a 95\% concentrated ethanol solution at the end of the canal disinfection phase to create a more dry environment allowing a deeper penetration of endodontic sealers inside dentinal tubules. ${ }^{[34,35]}$ New irrigants today used are associated with surfactants, chelators, and tetracyclines such as Tetraclean ${ }^{\circledR}$, a mixture of doxycycline hyclate, an acid, and a detergent. ${ }^{[36,37]}$ It is able to eliminate microorganisms and smear layer in dentinal tubules of infected root canals with a final 5 min rinse; ${ }^{[20]}$ BioPure MTAD is a mixture of antibiotic comprising doxycycline hyclate: $150 \mathrm{mg} / 5 \mathrm{ml}(3 \%)$, citric acid $(4.25 \%)$, and a detergent $(0.5 \%)$ - polysorbate 80 - or tween 80 . It has been investigated as an effective solution for both removing the smear layer and disinfecting the root canal system;; ${ }^{[38]}$ QMix, a product that is composed of a polyamino carboxylic acid chelating agent, a bisbiguanide antimicrobial agent, a surfactant, and deionized water. ${ }^{[39]}$ Furthermore, QMix ${ }^{\mathrm{TM}}$ does not interact with remnant $\mathrm{NaOCl}$ to generate a precipitate if used as directed for the final rinse and its ability to penetrate into patent, smear plug-free dentin to kill bacteria present has been demonstrated using a novel model with potentially significant clinical outcomes and implications. ${ }^{[40]}$

A detailed list of every single type of irrigant used in an endodontic treatment, including their most important features, such as their effects on organic or inorganic tissues, antibacterial activity, and cost, is shown in Table 2. 


\begin{tabular}{|c|c|c|c|c|c|c|c|}
\hline & \multicolumn{7}{|c|}{ Parameters } \\
\hline & $\begin{array}{l}\text { Efficacy } \\
\text { on organic } \\
\text { residues }\end{array}$ & $\begin{array}{l}\text { Efficacy on } \\
\text { inorganic } \\
\text { residues }\end{array}$ & $\begin{array}{l}\text { Antibacterial } \\
\text { activity }\end{array}$ & $\begin{array}{l}\text { Damage to the } \\
\text { surrounding } \\
\text { periodontal tissues }\end{array}$ & $\begin{array}{l}\text { Manageability (bad smell, } \\
\text { clothes staining and } \\
\text { others) }\end{array}$ & Cost & $\begin{array}{l}\text { Enlargement } \\
\text { of dentinal } \\
\text { tubules }\end{array}$ \\
\hline \multicolumn{8}{|l|}{ Irrigants } \\
\hline $\mathrm{NaOCl}$ & Yes & No & Yes & Yes & Bad & Low & High \\
\hline EDTA & No & Yes & No & Very low & Good & Low & High \\
\hline Citric acid & Yes & Yes & Yes & Yes & $\mathrm{N} / \mathrm{A}$ & Low & Low \\
\hline $\begin{array}{l}\text { Digluconate } \\
\text { chlorhexidine }\end{array}$ & No & No & Yes & No & Good & Low & Not influenced \\
\hline Tetraclean & Yes & Yes & Yes & No & Good & High & High \\
\hline BioPure MTDA & Yes & Yes & Yes & No & Good & High & High \\
\hline QMix & Yes & Yes & Yes & No & Good & High & High \\
\hline
\end{tabular}

\section{Problems related to the use of irrigants}

The root canal system has a large surface consisting of dentinal tubules openings that can be colonized by bacteria. During the shaping phase of endodontic space, ${ }^{[41]}$ the smear layer produced is compacted in the anastomosis, isthmus areas, and over tubules openings produced by the blades of endodontic instruments. The smear layer deposited in these areas consists of inorganic residues and bacterial biofilm that are unlikely to be removed by root canal irrigation. ${ }^{[42]}$

A few key factors are responsible for the effectiveness of an irrigation solution inside the canal system. First, to perform its function, the irrigation solution must be in contact with both the tissues, which it must act on, and the microorganisms to destroy. Frequent, if not continuous, irrigation replacement allows better results, considering the buffering effect due to the loss of chlorine of the dentin ${ }^{[43]}$ and the narrow spaces of the root canal system. Another key factor for the effectiveness of irrigant solutions is their time of action. In fact, to achieve a complete disinfection of the root canal system, one has to let the $\mathrm{NaOCl}$ solution act inside the canal for, at least, $30 \mathrm{~min}$, because it has been proven that, if used for a shorter time, the treatment outcome decreases.

A factor directly influencing the cleaning of the root canal system is the one determined by the mechanical effect of irrigants on canal walls, called shear stress. ${ }^{[44]}$ It is the force exerted on the canal surface by the flow of irrigant solutions.

Among the most commonly used instruments for root canal irrigation, syringes with a capacity of $<5 \mathrm{ml}$ are used to avoid exerting too much pressure on canal walls, to prevent accidental spills of $\mathrm{NaOCl}$ that may stain patients' clothes or irritate their eyes or face. While irrigating the root canal system, the clinician should distinguish, with the help of the dental assistant, the syringe containing $\mathrm{NaOCl}$ from the one filled with EDTA, a crucial point for the endodontic success.

Endodontic irrigation needles have a diameter of $0.42 \mathrm{~mm}-27 \mathrm{G}$ or $0.31 \mathrm{~mm}-30 \mathrm{G}$. Scientific research has shown that the irrigation efficacy is available only around the needle tip of the syringe; therefore, it is highly recommended to use a needle that penetrates as close as possible to the root apex without increasing the risk of leaking $\mathrm{NaOCl}$ in the surrounding periodontal space, ${ }^{[45-47]}$ since not only does it have antimicrobial activity but it also has oxidizing and hydrolyzing features that can lead to severe tissue damages. Some authors have mentioned clinical situations where $\mathrm{NaOCl}$ was inadvertently injected into the maxillary sinus ${ }^{[48,49]}$ or was unintentionally injected into the oral mucosa. ${ }^{[50]}$ This complication occurs in the teeth with wide apical foramina or when the apical constriction is destroyed during root canal preparation. In addition, extreme pressure during irrigation may result in contact of large volumes of the irrigant with the apical tissues.

It is of critical importance for dental practitioners to be able to recognize immediately the clinical signs and symptoms of $\mathrm{NaOCl}$ apical extrusion. Such event generally follows a typical pattern, starting with acute pain, swelling, and redness, followed by bruising and then by progressive swelling involving the infraorbital area or mouth angle depending on the site of $\mathrm{NaOCl}$ injection. This subsequently leads to a profuse hemorrhage often manifesting intraorally from the orifice of the tooth, leading to numbness or weakness of the facial nerve and secondary infection, sinusitis, and cellulitis. ${ }^{[51,52]}$ 
There is not a defined guideline on how to clinically manage this complication; however, daily practice has suggested that treatment should point at the principles of reducing swelling, controlling pain, and preventing secondary infection. Immediate irrigation with normal saline is a key step to reduce tissue damage. Tissue contact with $\mathrm{NaOCl}$ should be minimized by allowing the solution and exudates to filter out through the root canal orifices. Local and oral analgesics may be helpful to alleviate pain. External compression along with cold packs on the affected area is advised to relieve discomfort and reduce edema. After about $6 \mathrm{~h}$, cold packs must be replaced by warm compresses for several days. ${ }^{[51]}$ Steroid may be used to minimize edema. Antibiotics might be needed to prevent secondary infection. The routine use of antibiotics is controversial. Antibiotics should be administered only if there is any clinical evidence of wound infection or if necrosis is expected. ${ }^{[50]}$

\section{Methods to upgrade irrigant activity}

To obtain an appropriate disinfection of the apical portion of the canal, it is important to flood the area using a syringe, an effective method due to the churning of the liquid. ${ }^{[53]}$

Heating the irrigating solution is the most common method to enhance the $\mathrm{NaOCl}$ action. This can take place outside the root canal system inside special containers or by heating the syringes or using ultrasonic inserts. ${ }^{[54]}$

High temperatures increase $\mathrm{NaOCl}$ reaction rate, positively influencing its antibacterial action and its ability in dissolving organic residues. Heating $\mathrm{NaOCl}$ to $50^{\circ} \mathrm{C}-60^{\circ} \mathrm{C}$ is highly recommended. ${ }^{[54]}$

A simple method to increase $\mathrm{NaOCl}$ cleansing action is to shake it inside the canal by moving a gutta-percha cone, adapted to the canal shape, with 2-3-mm amplitude movements inside and the canal. Otherwise, a manual tool such as a carrier, a finger spreader, or a k-file can be used. ${ }^{[55]}$ This movement causes a sufficient hydrodynamic effect making the irrigant solution to penetrate into the narrowest spaces. ${ }^{[5]}$ One must remember that this method is useful in the replacement of the irrigant inside the root canal system only but does not enhance its chemical properties. In other words, shaking the irrigant solution does not improve its reaction rate but increases its surface contact with the canal walls and also reduces the vapor lock effect. The vapor lock effect is the formation of gas bubbles inside the canal, especially in the apical third, caused by the digestion of organic residues by the $\mathrm{NaOCl}$ solution, reducing the penetration of irrigants and so blocking their interaction with the canal walls and inhibiting their antimicrobial and digestive activities: using a mechanical activation of the irrigant solutions can reduce this effect. ${ }^{[57]}$ There are other simple and cost-effective methods to increase the action of irrigants. These involve the use of ultrasonic waves. There are two types of ultrasonic activation: first, the passive one, defined as Passive ultrasonic irrigation (PUI), with the introduction of the irrigant solution inside the canal and then the ultrasonic tip, without touching the canal walls, and the second one, defined as ultrasonic needle irrigation (UNI), where the activation of the irrigant solution is performed simultaneously with its administration inside the canal. ${ }^{[58]}$ PUI uses cut-free ultrasonic inserts that reduce the possibility of damages of the canal anatomy due to accidental contact. ${ }^{[59]}$ The vibration of the ultrasonic insert produces an acoustic stream that generates a shear stress sufficient to dislocate the debris of instrumented canals. ${ }^{[60]}$ It inserts vibrate at a frequency of $25-30 \mathrm{kHz}$, since lower frequencies produce sonic vibrations but not ultrasonic vibrations. Acoustic streaming creates microcavitation (small voids) that implodes shaking the solution inside the canal and improving the removal of the smear layer as well as improving the penetration of the liquid into the apical third of the canal. There is also the improvement of the reaction rate due to the irrigant solution temperature rise. The UNI ultrasonic techniques involve the outflow of the irrigant solution from a 25G diameter needle that simultaneously vibrates at ultrasonic frequencies. ${ }^{[61]}$ This method has the advantage of increasing both the shear stress and the reaction rate, but there is an increased risk of extruding the irrigant solution beyond the apex.

There are also sonic systems to improve the irrigation of root canal system: they produce a movement in the irrigation area that results in improved cleansing compared to traditional irrigation with a single syringe but being inferior if compared to the ultrasonic method. This system causes an increase of the shear stress, improving the elimination of the smear layer but does not increase the reaction rate. ${ }^{[61-63]}$ If one wants to avoid the extrusion of the irrigant solutions beyond the apex, the use of the EndoVac negative-pressure system is highly recommended. The EndoVac system is composed of three components: the master delivery tip (MDT), the instrument that introduces the $\mathrm{NaOCl}$ solution inside the pulp chamber with a metallic tubule while simultaneously aspirating 
it with a rubber tubule; the macrocannule made of propylene mounted on a titanium insert, which is able to remove the debris from the middle-third and the coronal third of the canal; the microcannule with an external diameter of $0.32 \mathrm{~mm}$ and 12 holes of $0.10 \mathrm{~mm}$ of diameter located at a $0.2-0.7-\mathrm{mm}$ distance from the tip used to aspirate the $\mathrm{NaOCl}$ solution from the apex in the last $0.2 \mathrm{~mm}$ of the canal. For its correct application, up to the anatomical apex of the tooth, the canal must have a $4 \%$ taper and an apical foramen of at least a diameter of $0.35 \mathrm{~mm}$. The irrigant injected by the MDT into the pulp chamber (that must never be located shorter than $5 \mathrm{~mm}$ from the canal opening) floods the canal and then is drained into the microcannule, avoiding so its extrusion beyond the apex and efficiently removing the debris and the gas bubbles from it. ${ }^{[64]}$ All this should be done moving the macro- and micro-cannules up and down inside the canal for $30 \mathrm{~s}$ and then leaving them still for $60 \mathrm{~s}$. A proper utilization of this system should be made of three microcycles: the first one using a $5 \%-6 \%$ concentrated $\mathrm{NaOCl}$ solution; the second one using a $15 \%-17 \%$ concentrated EDTA solution; and the final one using again a $5 \%-6 \%$ concentrated $\mathrm{NaOCl}$ solution. Studies have shown that this method improves antibacterial action compared to the use of a normal syringe, ${ }^{[65]}$ leading to an improvement of the shear stress along the canal walls and the elimination of vapor lock-related issues. LAI has recently been introduced as a photoactivation method and is an efficient one. The mechanism of action consists in the generation of microcavitation and subsequent implosion of irrigant bubbles due to the rapid absorption of laser energy using erbium: yttrium-aluminium-garnet (Er: YAG) and diode lasers. Photoactivation techniques with cavitation lead to better results than ultrasonic methods, if used for the same amount of time, with greater removal of debris, ${ }^{[66]}$ a longer lasting and increased reaction rate, and an increased irrigant temperature. ${ }^{[67]}$ The major disadvantages include the cost of laser and the risk of apex extrusion. ${ }^{[68]}$ The same problems can be found with PIPS. ${ }^{[69,70]}$ The following technique involves the use of an Er: YAG laser with subassertive power in a pulsating mode, which creates a series of extremely effective photoacoustic waves for the removal of the smear layer. A very detailed comparison between the methods listed above, including their different effects on various features such as vapor lock effect and shear stress, is included in Table 3.

\section{CONCLUSION}

The main problems related to the use of irrigant solutions, which are highly underlined in the literature, are their inability to reach the apical third and most complex anatomical structures (isthmi and anastomosis), their effectiveness being influenced by the presence of infected organic and inorganic debris, the clinical usage time, and their toxicity to the periapical tissues.

The inability to reach the apex to remove the smear layer in an appropriate manner can be solved using ultrasonic activation or photoactivation systems that lead to an improvement of both the shear stress and the reaction rate, with greater antimicrobial activity. ${ }^{[71]}$ However, both can lead to an increased risk of hypochlorite apex extrusion. ${ }^{[72]}$ This can be avoided using the EndoVac negative-pressure system, ${ }^{[73,74]}$

\begin{tabular}{|c|c|c|c|c|c|}
\hline & \multicolumn{5}{|c|}{ Parameters } \\
\hline & Reaction rate & Shear stress & Vapor lock effect & Apex extrusion & Alteration of canal anatomy \\
\hline \multicolumn{6}{|l|}{ Methods of activation } \\
\hline Heating & Increased & Not influenced & Not influenced & Not influenced & Not influenced \\
\hline Mechanical activation & Not influenced & Increased & Reduced & Not influenced & Increased \\
\hline \multicolumn{6}{|l|}{ Ultrasonic } \\
\hline PUI & Increased & Increased & Reduced & $\begin{array}{l}\text { Not influenced } \\
\text { from } 2 \mathrm{~mm} \text { apex }\end{array}$ & Increased \\
\hline UNI & Increased & Increased & Reduced & Increased & Increased \\
\hline Sonic & Not influenced & Increased & Reduced & $\begin{array}{l}\text { Not influenced } \\
\text { from } 2 \mathrm{~mm} \text { apex }\end{array}$ & Increased \\
\hline \multicolumn{6}{|l|}{ Photoactivation } \\
\hline LAI & Increased & Increased & Reduced & Increased & Increased \\
\hline PIPS & Increased & Increased & Reduced & Increased & Increased \\
\hline $\begin{array}{l}\text { Negative-pressure } \\
\text { gradient (EndoVac) }\end{array}$ & Not influenced & Increased & Reduced & Reduced & Not influenced \\
\hline
\end{tabular}


which provides a canal already shaped with an apex $0.35 \mathrm{~mm}$ in diameter. The last two methods also lead to a reduction of the vapor lock effect, which prevents the exchange of the irrigant solution in the apical third. ${ }^{[75,76]}$

For an ideal irrigation protocol, it is essential to use a $5.25 \%$ concentrated $\mathrm{NaOCl}$ solution for a suitable time during both the shaping the final irrigation phases, alternating the use of $\mathrm{NaOCl}$ with EDTA.

\section{Financial support and sponsorship \\ Nil.}

\section{Conflicts of interest}

There are no conflicts of interest.

\section{REFERENCES}

1. Sjögren U, Figdor D, Persson S, Sundqvist G. Influence of infection at the time of root filling on the outcome of endodontic treatment of teeth with apical periodontitis. Int Endod J 1997;30:297-306.

2. Kakehashi S, Stanley HR, Fitzgerald RJ. The effects of surgical exposures of dental pulps in germ-free and conventional laboratory rats. Oral Surg Oral Med Oral Pathol 1965;20:340-9.

3. Sakko M, Tjäderhane L, Rautemaa-Richardson R. Microbiology of root canal infections. Prim Dent J 2016;5:84-9.

4. Stuart CH, Schwartz SA, Beeson TJ, Owatz CB. Enterococcus faecalis: Its role in root canal treatment failure and current concepts in retreatment. J Endod 2006;32:93-8.

5. Estrela C, Silva JA, de Alencar AH, Leles CR, Decurcio DA. Efficacy of sodium hypochlorite and chlorhexidine against Enterococcus faecalis - A systematic review. J Appl Oral Sci 2008;16:364-8.

6. Saatchi M, Shokraneh A, Navaei H, Maracy MR, Shojaei H. Antibacterial effect of calcium hydroxide combined with chlorhexidine on Enterococcus faecalis: A systematic review and meta-analysis. J Appl Oral Sci 2014;22:356-65.

7. van der Waal SV, Connert T, Crielaard W, de Soet JJ. In mixed biofilms Enterococcus faecalis benefits from a calcium hydroxide challenge and culturing. Int Endod J 2016;49:865-73.

8. Sangalli J, Júnior EG, Bueno CR, Jacinto RC, Sivieri-Araújo G, Filho JE, et al. Antimicrobial activity of psidium cattleianum associated with calcium hydroxide against Enterococcus faecalis and Candida albicans: An in vitro study. Clin Oral Investig 2018;22:2273-9.

9. Del Carpio-Perochena A, Kishen A, Felitti R, Bhagirath AY, Medapati MR, Lai C, et al. Antibacterial properties of chitosan nanoparticles and propolis associated with calcium hydroxide against single- and multispecies biofilms: An in vitro and in situ study. J Endod 2017;43:1332-6.

10. Mehta S, Verma P, Tikku AP, Chandra A, Bains R, Banerjee G, et al. Comparative evaluation of antimicrobial efficacy of triple antibiotic paste, calcium hydroxide, and a proton pump inhibitor against resistant root canal pathogens. Eur J Dent 2017;11:53-7.

11. Silveira CF, Cunha RS, Fontana CE, de Martin AS, Gomes BP, Motta RH, et al. Assessment of the antibacterial activity of calcium hydroxide combined with chlorhexidine paste and other intracanal medications against bacterial pathogens. Eur J Dent 2011;5:1-7.

12. Tomson PL, Simon SR. Contemporary cleaning and shaping of the root canal system. Prim Dent J 2016;5:46-53.

13. Dioguardi M, Troiano G, Laino L, Lo Russo L, Giannatempo G, Lauritano F, et al. ProTaper and WaveOne systems three-dimensional comparison of device parameters after the shaping technique. A micro-CT study on simulated root canals. Int J Clin Exp Med 2015;8:17830-4.

14. Pintor AV, Dos Santos MR, Ferreira DM, Barcelos R, Primo LG, Maia LC, et al. Does smear layer removal influence root canal therapy outcome? A systematic review. J Clin Pediatr Dent 2016;40:1-7.
15. Troiano G, Dioguardi M, Cocco A, Giuliani M, Fabiani C, D'Alessandro A, et al. Centering ability of ProTaper next and WaveOne classic in J-shape simulated root canals. ScientificWorldJournal 2016;2016:1606013.

16. Troiano G, Dioguardi M, Cocco A, Giannatempo G, Laino L, Ciavarella D, et al. Influence of operator's experience on the shaping ability of protaper universal and WaveOne systems: A comparative study on simulated root canals. Open Dent J 2016;10:546-52.

17. Torabinejad M, Handysides R, Khademi AA, Bakland LK. Clinical implications of the smear layer in endodontics: A review. Oral Surg Oral Med Oral Pathol Oral Radiol Endod 2002;94:658-66.

18. Jena A, Sahoo SK, Govind S. Root canal irrigants: A review of their interactions, benefits, and limitations. Compend Contin Educ Dent 2015;36:256-61.

19. Zehnder M. Root canal irrigants. J Endod 2006;32:389-98.

20. Kandaswamy D, Venkateshbabu N. Root canal irrigants. J Conserv Dent 2010;13:256-64.

21. Bryce G, O'Donnell D, Ready D, Ng YL, Pratten J, Gulabivala K, et al. Contemporary root canal irrigants are able to disrupt and eradicate single- and dual-species biofilms. J Endod 2009;35:1243-8.

22. Tosić G, Miladinović M, Kovaević M, Stojanović M. Choice of root canal irrigants by serbian dental practitioners. Vojnosanit Pregl 2016;73:47-52.

23. Radcliffe CE, Potouridou L, Qureshi R, Habahbeh N, Qualtrough A, Worthington $\mathrm{H}$, et al. Antimicrobial activity of varying concentrations of sodium hypochlorite on the endodontic microorganisms Actinomyces israelii, A. naeslundii, Candida albicans and Enterococcus faecalis. Int Endod J 2004;37:438-46.

24. Clegg MS, Vertucci FJ, Walker C, Belanger M, Britto LR. The effect of exposure to irrigant solutions on apical dentin biofilms in vitro. J Endod 2006;32:434-7.

25. Haapasalo M, Shen Y, Wang Z, Gao Y. Irrigation in endodontics. Br Dent J 2014;216:299-303.

26. Bosch-Aranda ML, Canalda-Sahli C, Figueiredo R, Gay-Escoda C. Complications following an accidental sodium hypochlorite extrusion: A report of two cases. J Clin Exp Dent 2012;4:e194-8.

27. de Sermeño RF, da Silva LA, Herrera H, Herrera H, Silva RA, Leonardo MR, et al. Tissue damage after sodium hypochlorite extrusion during root canal treatment. Oral Surg Oral Med Oral Pathol Oral Radiol Endod 2009;108:e46-9.

28. Gomes BP, Vianna ME, Zaia AA, Almeida JF, Souza-Filho FJ, Ferraz CC, et al. Chlorhexidine in endodontics. Braz Dent 2013;24:89-102.

29. Bernardi A, Teixeira CS. The properties of chlorhexidine and undesired effects of its use in endodontics. Quintessence Int 2015;46:575-82.

30. Ballal NV, Jain I, Tay FR. Evaluation of the smear layer removal and decalcification effect of QMix, maleic acid and EDTA on root canal dentine. J Dent 2016;51:62-8.

31. Ram Z. Chelation in root canal therapy. Oral Surg Oral Med Oral Pathol 1980;49:64-74.

32. Zehnder M, Schmidlin P, Sener B, Waltimo T. Chelation in root canal therapy reconsidered. J Endod 2005;31:817-20.

33. Rossi-Fedele G, Doğramaci EJ, Guastalli AR, Steier L, de Figueiredo JA. Antagonistic interactions between sodium hypochlorite, chlorhexidine, EDTA, and citric acid. J Endod 2012;38:426-31.

34. Thiruvenkadam G, Asokan S, John B, Priya PG. Effect of 95\% ethanol as a final irrigant before root canal obturation in primary teeth: An in vitro study. Int J Clin Pediatr Dent 2016;9:21-4.

35. Kara Tuncer A, Tuncer S. Effect of different final irrigation solutions on dentinal tubule penetration depth and percentage of root canal sealer. J Endod 2012;38:860-3.

36. Torabinejad M, Khademi AA, Babagoli J, Cho Y, Johnson WB Bozhilov K, et al. A new solution for the removal of the smear layer. J Endod 2003;29:170-5.

37. Giardino L, Ambu E, Becce C, Rimondini L, Morra M. Surface tension comparison of four common root canal irrigants and two new irrigants containing antibiotic. J Endod 2006;32:1091-3.

38. Yadav HK, Tikku AP, Chandra A, Yadav RK, Patel DK. Efficacy of etidronic acid, bioPure MTAD and smearClear in removing calcium ions from the root canal: An in vitro study. Eur J Dent 2015;9:523-8.

39. Haapasalo M, Shen Y, Qian W, Gao Y. Irrigation in endodontics. Dent Clin North Am 2010;54:291-312.

40. Ma J, Wang Z, Shen Y, Haapasalo M. A new noninvasive model to study the effectiveness of dentin disinfection by using confocal laser 
scanning microscopy. J Endod 2011;37:1380-5.

41. Troiano G, Laino L, Dioguardi M, Giannatempo G, Lo Muzio L, Lo Russo L, et al. Mandibular class II furcation defect treatment: Effects of the addition of platelet concentrates to open flap: A systematic review and meta-analysis of randomized clinical trials. J Periodontol 2016;87:1030-8.

42. Ahmed HM, Neelakantan P, Dummer PM. A new system for classifying accessory canal morphology. Int Endod J 2018;51:164-76.

43. Arias-Moliz MT, Morago A, Ordinola-Zapata R, Ferrer-Luque CM, Ruiz-Linares M, Baca $\mathrm{P}$, et al. Effects of dentin debris on the antimicrobial properties of sodium hypochlorite and etidronic acid. J Endod 2016;42:771-5.

44. van der Sluis LW. Endodontics in motion: New concepts, materials and techniques 3 . The role of irrigants during root canal treatment. Ned Tijdschr Tandheelkd 2015;122:533-8.

45. Mehra P, Clancy C, Wu J. Formation of a facial hematoma during endodontic therapy. J Am Dent Assoc 2000;131:67-71.

46. Mehdipour O, Kleier DJ, Averbach RE. Anatomy of sodium hypochlorite accidents. Compend Contin Educ Dent 2007;28:544-6, $548,550$.

47. Zhu WC, Gyamfi J, Niu LN, Schoeffel GJ, Liu SY, Santarcangelo F, et al. Anatomy of sodium hypochlorite accidents involving facial ecchymosis - A review. J Dent 2013;41:935-48.

48. Kavanagh CP, Taylor J. Inadvertent injection of sodium hypochlorite into the maxillary sinus. Br Dent J 1998;185:336-7.

49. Ehrich DG, Brian JD Jr., Walker WA. Sodium hypochlorite accident: Inadvertent injection into the maxillary sinus. J Endod 1993;19:180-2.

50. Motta MV, Chaves-Mendonca MA, Stirton CG, Cardozo HF. Accidental injection with sodium hypochlorite: Report of a case. Int Endod J 2009;42:175-82.

51. Hülsmann M, Hahn W. Complications during root canal irrigation - Literature review and case reports. Int Endod J 2000;33:186-93.

52. Tasdemir T, Er K, Celik D, Yildirim T. Effect of passive ultrasonic irrigation on apical extrusion of irrigating solution. Eur J Dent 2008;2:198-203.

53. Boutsioukis C, Lambrianidis T, Kastrinakis E. Irrigant flow within a prepared root canal using various flow rates: A computational fluid dynamics study. Int Endod J 2009;42:144-55.

54. Sirtes G, Waltimo T, Schaetzle M, Zehnder M. The effects of temperature on sodium hypochlorite short-term stability, pulp dissolution capacity, and antimicrobial efficacy. J Endod 2005;31:669-71.

55. Gu LS, Kim JR, Ling J, Choi KK, Pashley DH, Tay FR, et al. Review of contemporary irrigant agitation techniques and devices. J Endod 2009;35:791-804.

56. Salzgeber RM, Brilliant JD. An in vivo evaluation of the penetration of an irrigating solution in root canals. J Endod 1977;3:394-8.

57. Agarwal A, Deore RB, Rudagi K, Nanda Z, Baig MO, Fareez MA, et al. Evaluation of apical vapor lock formation and comparative evaluation of its elimination using three different techniques: An in vitro study. J Contemp Dent Pract 2017;18:790-4.

58. Gutarts R, Nusstein J, Reader A, Beck M. In vivo debridement efficacy of ultrasonic irrigation following hand-rotary instrumentation in human mandibular molars. J Endod 2005;31:166-70.

59. van der Sluis LW, Versluis M, Wu MK, Wesselink PR. Passive ultrasonic irrigation of the root canal: A review of the literature. Int Endod J 2007;40:415-26.

60. Mohammadi Z, Shalavi S, Giardino L, Palazzi F, Asgary S. Impact of ultrasonic activation on the effectiveness of sodium hypochlorite: A review. Iran Endod J 2015;10:216-20.

61. Ferreira RB, Marchesan MA, Silva-Sousa YT, Sousa-Neto M. Effectiveness of root canal debris removal using passive ultrasound irrigation with chlorhexidine digluconate or sodium hypochlorite individually or in combination as irrigants. J Contemp Dent Pract 2008;9:68-75.

62. Barnett F, Godick B, Tronstad L. Clinical suitability of a sonic vibratory endodontic instrument. Endod Dent Traumatol 1985;1:77-81.

63. Velvart P. Efficiency of root canal preparation with ultrasound using various irrigants. Schweiz Monatsschr Zahnmed 1987;97:756-65.

64. Schoeffel GJ. The endoVac method of endodontic irrigation: Safety first. Dent Today 2007;26:92, 94, 96.

65. Konstantinidi E, Psimma Z, Chávez de Paz LE, Boutsioukis C. Apical negative pressure irrigation versus syringe irrigation: A systematic review of cleaning and disinfection of the root canal system. Int Endod J 2017;50:1034-54.

66. Wang X, Cheng X, Liu B, Liu X, Yu Q, He W, et al. Effect of laser-activated irrigations on smear layer removal from the root canal wall. Photomed Laser Surg 2017;35:688-94.

67. Hasheminia SM, Birang R, Feizianfard M, Nasouri M. A comparative study of the removal of smear layer by two endodontic irrigants and Nd: YAG laser: A scanning electron microscopic study. ISRN Dent 2012;2012:620951.

68. George R, Meyers IA, Walsh LJ. Laser activation of endodontic irrigants with improved conical laser fiber tips for removing smear layer in the apical third of the root canal. J Endod 2008;34:1524-7.

69. Arslan D, Kustarci A. Efficacy of photon-initiated photoacoustic streaming on apically extruded debris with different preparation systems in curved canals. Int Endod J 2018;51 Suppl 1:e65-72.

70. Azim AA, Aksel H, Margaret Jefferson M, Huang GT. Comparison of sodium hypochlorite extrusion by five irrigation systems using an artificial root socket model and a quantitative chemical method. Clin Oral Investig 2018;22:1055-61.

71. Virdee SS, Seymour DW, Farnell D, Bhamra G, Bhakta S. Efficacy of irrigant activation techniques in removing intracanal smear layer and debris from mature permanent teeth: A systematic review and meta-analysis. Int Endod J 2018;51:605-21.

72. Muhammad OH, Chevalier M, Rocca JP, Brulat-Bouchard N, Medioni E. Photodynamic therapy versus ultrasonic irrigation: Interaction with endodontic microbial biofilm, an ex vivo study. Photodiagnosis Photodyn Ther 2014;11:171-81.

73. Mancini M, Cerroni L, Iorio L, Armellin E, Conte G, Cianconi L, et al. Smear layer removal and canal cleanliness using different irrigation systems (EndoActivator, endoVac, and passive ultrasonic irrigation): Field emission scanning electron microscopic evaluation in an in vitro study. J Endod 2013;39:1456-60.

74. Kungwani ML, Prasad KP, Khiyani TS. Comparison of the cleaning efficacy of EndoVac with conventional irrigation needles in debris removal from root canal. An in vivo study. J Conserv Dent 2014;17:374-8.

75. Karade P, Chopade R, Patil S, Hoshing U, Rao M, Rane N, et al. Efficiency of different endodontic irrigation and activation systems in removal of the smear layer: A scanning electron microscopy study. Iran Endod J 2017;12:414-8.

76. Tay FR, Gu LS, Schoeffel GJ, Wimmer C, Susin L, Zhang K, et al. Effect of vapor lock on root canal debridement by using a side-vented needle for positive-pressure irrigant delivery. J Endod 2010;36:745-50. 